\title{
The Impact of the Quality of Public Policies by Improving Morals and Ethics in Public Services for Bureaucratic Reform
}

\author{
Mubarok \\ UIN Sunan Gunung Djati Bandung, Indonesia \\ Email: mubarok.crd@gmail.com
}

\begin{abstract}
In this reform era, public policy has become an essential matter for every citizen. Therefore, the government must be able to make public policies that are pro-society. Here the government is required not only to make right or wrong policies based on law but also to see the ethical and moral dimensions in society. An act that is law-abiding is not inherently moral and ethically correct. This study aims to clarify the importance of morality and ethics for decision-making officials by offering an overview of public policy ethics in Indonesia in general.
\end{abstract}

Keywords: Ethics, Moral, Public Policy, Public Service

\section{A. INTRODUCTION}

Following the concept of transparency in a democratic society, state administrators must be open to public rights in order to obtain accurate, truthful, and nondiscriminatory information on state administration (Dawes \& Helbig, 2010). According to Government Regulation No. 61 of 2009 concerning information disclosure, it is regulated on the rights and responsibilities and obligations of the public and state administrators in a balanced manner. This is intended to obtain legal protection in exercising their rights to capture and convey information about State Administrators. Freedom to exercise this right must be followed by accountability for reporting facts and events through compliance and reverence for commonly accepted moral principles and relevant laws and regulations (Obama 2009).

Every society or nation must have moral standards to base their attitudes, behavior, and actions to achieve what they aspire to with that moral guidance, What is good and bad, right and wrong, and which is called ideal and not ideal (Inglis, 1977). So, wherever we live in society, community, and state, the position of ethics can not be ignored. Both people are involved in ethics. It is understood that the state or public administration has the free right to act in order to provide public services and to establish general welfare. Thus, the bureaucracy is given regulatory power, namely legal action to regulate people's lives through an instrument called a public policy (Reinicke \& Copeland, 1998). 
As a legal document, public policy requires directives (musts) or prohibitions. Anyone who violates a law or carries out specifically forbidden acts will be subject to such penalties. That is the ethical ramifications of public policy. In other words, the legal approach to public policy does not pay attention to aspects of the effects or advantages of legislation (Howlett \& Perl, 2009). That is why we often see that government proposals are frequently rejected by the electorate (electorate veto) because they do not take the ethical and moral aspects of society into account. Public policy should, therefore, not only prioritize the ideals of the right-the wrong but must be further established for the socialization of the good-the false ideals. Because, according to the statute, an action that is right is not inherently morally acceptable. (Dwivedi, 1987).

The importance of public service orientation has long been expressed in the debate on public policy. The focal point is also focused on satisfying the identified needs, not the policymaker. Furthermore, the more researched and analyzed the scope of the sense of the definition of public services, the more relevant the basic function of public services is applied in the real world (McGregor et al. 2009).

Public organizations (government) as institutions that carry out the mission of public service have recently been increasingly campaigning and competing with each other to provide and implement the essential meaning of these public services; however, in their implementation, they are still far from the desired expectations in general, two items are important for government agencies to improve the definition of public services (Achnes, 2011). The first is the accountability factor for the enforcement of current policies. There, the organization must have a firm determination, through the vision and purpose of the company, to carry out its service functions properly. The second factor is the executive apparatus (bureaucrats), which performs these functions of service. Here, any person performing a service role must adhere to the organizational commitment set out in the vision and purpose of the organization. Suppose these two things are used as a reference when performing the functions of the service. In that case, it will shape the ethic used as a reference in any bureaucratic action to carry out their duties in complete (Sinambela, 2017).

The primary explanation that public services must be offered is the presence of public interest or public interest that must be addressed by the government since it is the government that has "duty" or duty. The government is supposed to carry out these programs effectively and make relevant political decisions about who gets what, how much, where, when, etc. Reality reveals that the government has no clear guidelines or instructions on legal or moral standards. 


\section{B. METHOD}

This research uses a qualitative approach to the literature review process. Data is obtained from a number of sources, such as papers, books, and writings relating to the research topic. The data is then processed in order to determine the findings of the analysis.

\section{RESULT AND DISCUSSION}

Spiller (2000) describes the concept of ethics with several meanings, one of which and what people commonly use is a habit, custom, or character and character. The great philosopher, Aristotle, said Spiller, has used the word ethics in describing moral philosophy, namely the science of what is usually done or the science of customs. Spiller also pointed out that ethics is conceived as a science with ethical concepts. In the Major Indonesian Dictionary, the word "ethics" is referred to as; (1) knowledge of what is good and evil and moral rights and obligations; (2) a list of moral standards or values; and (3) ideals of right and wrong obedience to by a community or society.

By paying attention to the several sources above, Spiller concluded that there are three basic definitions of ethics, namely: (1) ethics as moral principles and moral norms that are used by an individual or community to govern their behavior, or what is called a value system; (2) Ethics as a set of beliefs or universal ideals sometimes referred to as the "code of ethics;" and (3) as the science of good or evil, sometimes referred to as the "moral philosophy."

This opinion is similar to the advice written in The Encyclopedia of Philosophy, which uses ethics as (1) a way of life; (2) moral code or rules of conduct (Denhardt, 1988). One of Spiller's exciting descriptions (2000) is about the differentiation of the concept of ethics from the etiquette idea. Ethics more describes the norms about the act itself - that is, whether a law is allowed or not to be done, for example, taking someone's property without permission is never allowed. While etiquette describes how an act is carried out by humans, and applies only in association or interacting with other people, and tends to use solely in certain circles, for example giving something to another person with the left hand is a way that is not polite according to specific cultures, but nothing problems for other cultures. Because of that, etiquette is more relative, and tends to prioritize external symbols, when compared to ethics which tend to be universal and describe the inner attitude.

Public service in a narrow sense; a public service is an act of delivering goods and services to the community through government, either directly or by collaborations with the private sector and the community, on the basis of the form and nature of community needs, community capacity and the market. This definition illustrates the manner in which services are delivered. The public has been successfully served into a safe 
distribution network. This public service can be seen daily in the areas of administration, security, health, education, housing, clean water, telecommunications, transport, banks, etc. The aim of public services is to provide the best goods and services to the community. The best products and services fulfill what is promised or what society needs. Thus, the best public services provide satisfaction to the public, if necessary, to exceed public expectations. In a broad sense, the concept of public service is synonymous with public administration, namely sacrificing on behalf of others in achieving the public interest (Paarlberg et al. 2008). Within this sense, public services are more focused on how elements of public administration, such as policy-making, organizational design, and management processes, are used to function within delivering public services, where the government is the responsible provider (Moynihan \& Pandey, 2007).

Within the field of public services, ethics is characterized as the philosophy and ethical principles (code of ethics) or the moral or legal rules of conduct that public service providers or public administrators abide by. In the basis of the aforementioned principles of ethics and public services, what is defined by public service ethics is the nature of public management and the provision of public services, and is based in a set of codes of conduct or a code of ethics that governs 'good' matters, or vice versa, 'not good' to be avoided.

Lemons \& Browns (2013) say that in public service, there are four levels of ethics: Personal ethics or morals, namely giving a warning about good or bad, which depends on several factors, including the influence of parents, religious beliefs, culture, customs, and past experiences. Professional ethics, namely a series of norms or rules that guide the behavior of certain professions. Organizational ethics is a series of formal and informal rules and standards that guide the behavior and actions of the members of the organization concerned. Social ethics, namely norms that guide community members' behavior and movements so that the integrity of the group and community members, is always maintained or maintained.

The existence of this ethical hierarchy tends to confuse the decisions of public service actors because all the moral values of these four levels are competing with each other. For example, placing people in certain positions or positions is very dependent on the ethics adhered to by powerful officials. If social ethics strongly influences him, he will go ahead of people from his area, often giving the impression of Corruption, Collusion, and Nepotism (Zakaria \& Setyoko, 2012). If organizational ethics dominate him, he will probably see the prevailing habits in the organization, such as using a system of "seniority," which prioritizes those who are most senior first or perhaps dominated by a merit system that will prioritize the most accomplished people. Thus, moral or ethical issues in this context ultimately depend on the level of ethics that dominates a key public service actor's decisions. This conflict between values of different ethical standards often 
confuses decision-makers so that sometimes they leave the final decision to others they trust or respect, such as higher officials, charismatic figures, "smart people," etc. (Masyar, 2011).

The implication of the dilemma described earlier is that it is difficult to judge whether public service actors have violated existing moral values or not, depending on their belief whether they are classified as absolutist or relativist. This may have created an atmosphere of corruption, collusion, and nepotism in our country.

A Code of Conduct is required. The Code of Ethics for Public Services in Indonesia is only limited to a variety of occupations, such as legal and medical experts. On the other hand, the code of ethics for certain occupations is still unclear (Maani, 2011). Many people say that we don't need a code of ethics because, in fact, we already have the principles of religion, ethics, morality, and even the oath of civil servants that is pronounced every flag apple. This view is not wrong, but it must be admitted that the lack of this code of conduct has given service providers the opportunity to ignore the public interest. The inclusion of the code of conduct itself acts more as a direct monitoring mechanism for the actions of staff or officials at work. For this case, what is more important is that the Code of Ethics is not only there but that it also assesses the extent of application of the code for effect. Also, on the basis of the compliance evaluation, the code of conduct is then still established or updated to meet the demands of changing times (Kusumawati, 2019). We need to learn from other countries that are already ethically advanced. Across the United States, for example, public service ethical awareness has grown to such an extent that even public service occupations have codes of ethics. Another example applicable to the public sector is the Code of Ethics of the American Society for Public Administration (ASPA), which has been updated repeatedly and continues to attract feedback and clarification from its members. Standards that are used as criteria for the actions of its members include dignity, reliability, fairness, fortitude, loyalty, attention, friendliness, sensitivity, prioritization of public interests over other interests, professionalism, professional development, open communication and accountability, imagination, commitment, usage of discretion in the public interest, confidentiality of information that should be held private, support for scheme merit and affirmative action initiatives (Henry et al . 2009).

Maturity and Ethical Flexibility, in the current operation of public services in Indonesia, we should always pay heed to this dilemma. In other words, public service providers must study universal ethical principles so they can be used as a reference for their actions. Nevertheless, these standards are also situation-bound, so that the adoption of these criteria should not be static. Acting in this way shows sophistication in ethics (Maani, 2011). 
Consensus dialog will help to overcome this problem. Our deficiency lies in the lack of restriction of a code of conduct. Likewise, there is still no right to investigate and challenge the standards of morality that apply. Even then, the laws of morality that already exist are static without recognizing the changing times. We always tend to allow ourselves to be governed by others so that there is no ethical autonomy. Often, we also encourage ourselves to give priority to particular interests, irrespective of the context, or where we work or are located. Putting one's community or tribe first is an act of guilt if placed in the sense of a public agency that seeks fair treatment for all tribes. This may be appropriate for private organizations, but not for public organizations. There must, therefore, be maturity to see where we are and what level of the ethical hierarchy is most appropriate to apply (Jumiati, 2012).

There are all of us among us who are very concerned about ethical or moral values, making complaints about moral violations. They are the ones who dare to reveal secrets and test moral and ethical violations. But the attempt to do this is sometimes seen as a dishonorable attempt, often even condemned by his actions, and his fate can be threatened. This experience tends to frighten them and develop a habit of not wanting to "bother" or not want to "deal" with the law or courts, where the incentives are not clear. As a result, opportunities from influential parties in public services continue to be open to committing acts of moral and ethical violations. Therefore, to improve morality in public services, protection of the complainants is needed, if necessary, special incentives (Bisri \& Asmoro, 2019).

The assessment of the successor government structure of the administrator is based not only on the achievement of the standards for productivity, economy, and other administrative values but also on the requirements of morality, in particular its commitment to the public interest. The underlying explanation that public services must be given is that there is a general interest or public interest that must be served by the government because it is the government that has "responsibility." In delivering such services, the government is required to carry them out effectively and to make informed political decisions on who gets what, how much, when, when, etc. (Henry et al. 2009).

Reality reveals that the government has no clear guidelines or instructions on legal or moral standards. The presumption that all government representatives are individuals who have been checked and always protect the interests of the public or community is still not correct. Most cases indicate that personal interests, families, associations, parties, and even higher structures control the actions of the bureaucrat or government apparatus. Bureaucrats, in this case, have no "independence" in acting ethically or, in other words, there is no "autonomy in ethics." Another explanation has something to do with the atmosphere within the system that the service itself offers. Denhardt shared a desire to pay attention to the individual dimensions of organizations (Denhardt, 1998). 
The policy of prioritizing "residents" is one example that is popular today. Another important reason is that the opportunity to take action that is contrary to the prevailing ethics in providing public services is enormous. Public services are not as straightforward as they could be expected. In other words, they are complex, both in terms of the value of providing the service itself and in terms of the best way to deliver the public services themselves.

Such complexities and uncertainties allow public service providers to take "discretion"-based, competent actions. And this flexibility is what often causes public service providers or government officials to act not following existing codes of ethics or behavioral guidelines. In the provision of public services, especially in Indonesia, moral and ethical violations can be observed starting from the public policy process (proposing programs, projects, and activities that are not based on reality), the design of public service organizations (structuring, formalization, dispersion of authority) which is very biased. Against specific interests, the public service management process is full of engineering and camouflage (starting from technical planning, financial management, human resources, information, etc.), all of which are evident from the characteristics of being not transparent, unresponsive, unaccountable, unfair, etc.

It cannot be denied that all these moral and ethical violations have been identified as one of the causes of the weakening of Indonesian governance. The main reasons for this tragedy were very complex, ranging from weaknesses in-laws and regulations, human mental attitudes, unsupportive socio-cultural values, history and state background, uncontrolled globalization, government systems, maturity in politics, etc. For Indonesia, the reform of morality that has occurred so far is still limited to lip service and does not touch the substance of moral change itself. Therefore, moral reform is a "big burden" in the future, and if it is not taken seriously, the process of "decay" will continue. It can have an impact on the disintegration of the nation.

\section{CONCLUSION}

Ethics more describes the norms about the act itself - that is, whether a law is allowed or not to be done, for example, taking someone's property without permission is never allowed. While etiquette describes how an act is carried out by humans, and applies only in association or interacting with other people, and tends to use solely in certain circles, for example giving something to another person with the left hand is a way that is not polite according to specific cultures, but nothing problems for other cultures. Because of that, etiquette is more relative, and tends to prioritize external symbols, when compared to ethics which tend to be universal and describe the inner attitude.

In the provision of public services, especially in Indonesia, moral and ethical violations can be observed starting from the public policy process (proposing programs, 
projects, and activities that are not based on reality), the design of public service organizations (structuring, formalization, dispersion of authority) which is very biased. Against particular interests, the public service management process which is full of engineering and camouflage (starting from technical planning, financial management, human resources, information, etc.), all of which are evident from the characteristics of being not transparent, unresponsive, unaccountable, unfair, It is hoped that the government bureaucracy will evaluate the forms of unethical services to further increase the capacity in services based on existing service standards.

\section{REFERENCES}

1. Achnes, S. (2011). Pelayanan Prima Sebagai Upaya Pelaksanaan Good Government. Jurnal Kebijakan Publik, 2(2).

2. Bisri, M. H., \& Asmoro, B. T. (2019). Etika Pelayanan Publik di Indonesia. Journal of Governance Innovation, 1(1), 59-76.

3. Dawes, S. S., \& Helbig, N. (2010, August). Information strategies for open government: Challenges and prospects for deriving public value from government transparency. International Conference on Electronic Government (pp. 50-60). Springer, Berlin, Heidelberg.

4. Denhardt, K. G. (1988). The ethics of public service: Resolving moral dilemmas in public organizations (No. 195). Greenwood Publishing Group.

5. Dwivedi, O. P. (1987). Ethics, the public service, and public policy: Some comparative reflections. International Journal of Public Administration, 10(1), 21-50.

6. Government Regulation No. 61 of 2009 concerning information disclosure

7. Henry, N., Goodsell, C. T., Lynn Jr, L. E., Stivers, C., \& Wamsley, G. L. (2009). Understanding excellence in public administration: The report of the task force on educating for excellence in the master of public administration degree of the American society for public administration. Journal of Public Affairs Education, 15(2), 117-133.

8. Howlett, M., Ramesh, M., \& Perl, A. (2009). Studying public policy: Policy cycles and policy subsystems (Vol. 3). Oxford: Oxford University Press.

9. Inglis, F. (1977). Nation and community: A landscape and its morality. The sociological review, 25(3), 489-514.

10. Jumiati, I. E. (2012). Dimensi etika dalam pelayanan publik Arti penting, dilema dan implikasinya Bagi pelayanan publik di Indonesia. Jurnal Administrasi Publik Volume 3, Nomor 1, Juni 2012, 3(1). 
11. Kusumawati, M. P. (2019). Harmonisasi Antara Etika Publik Dan Kebijakan Publik. Jurnal Yuridis, 6(1), 1.

12. Lemons, J., \& Brown, D. A. (Eds.). (2013). Sustainable development: Science, ethics, and public policy (Vol. 3). Springer Science \& Business Media.

13. Maani, K. D. (2010). Etika pelayanan publik. Jurnal Demokrasi, 9(1).

14. Mahsyar, A. (2011). Masalah Pelayanan Publik di Indonesia dalam Perspektif Administrasi Publik. Otoritas: Jurnal Ilmu Pemerintahan, 1(2).

15. McGregor, J. A., Camfield, L., \& Woodcock, A. (2009). Needs, wants, and goals: Wellbeing, quality of life, and public policy. Applied Research in Quality of Life, 4(2), 135-154.

16. Moynihan, D. P., \& Pandey, S. K. (2007). The role of organizations in fostering public service motivation. Public administration review, 67(1), 40-53.

17. Obama, B. (2009). Transparency and open government. Memorandum for the heads of executive departments and agencies.

18. Paarlberg, L. E., Perry, J. L., \& Hondeghem, A. (2008). From theory to practice: Strategies for applying public service motivation. Motivation in public management: The call of public service, 268-293.

19. Reinicke, W. H., \& Copeland, D. (1998). Global public policy: governing without government?. International Journal, 53(3), 597.

20. Safrony, M. L. (2012). Manajemen dan reformasi pelayanan publik dalam konteks birokrasi Indonesia: teori, kebijakan, dan implementasi. Aditya Media Pub..

21. Sinambela, L. P. (2017). Reformasi pelayanan publik. Bumi Akasara.

22. Sjamsuddin, S. (2006). Dasar-dasar dan teori administrasi publik. Yayasan pembangunan Nasional Malang.

23. Spiller, R. (2000). Ethical business and investment: A model for business and society. Journal of Business Ethics, 27(1-2), 149-160.

24. Wijaya, A. F., \& Danar, O. R. (2014). Manajemen Publik: Teori dan Praktik. Universitas Brawijaya Press.

25. Zakaria, Y., \& Setyoko, P. I. (2012). Pelibatan Masyarakat Sebagai Etika Dalam Formulasi Kebijakan Publik Guna Mencegah Praktik Korupsi1. Jurnal Ilmu Administrasi Unsoed. 